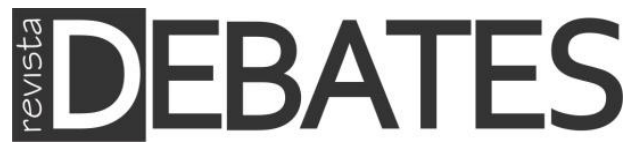

\title{
Corruption, accountability and citizen participation in protests in Latin America
}

\author{
Corrupção, accountability e participação civil em protestos na \\ América Latina
}

\section{Alejandro Avenburg}

\begin{abstract}
In the last few years street demonstrations broke out in Brazil as well as in other Latin American countries to protest against major corruption scandals. Various scholars studying the case of Brazil have argued that the economic recession was one of the conditions triggering public's reaction against corruption scandals (MELO, 2016; HAGOPIAN, 2016), as public opinion might tolerate corruption during times of economic boom - when government social programs can be expanded - but they are less likely to accept it during times of economic recession (BALAN, 2014). This article uses data from the LAPOP surveys 2010 to show that there is a systematic link between corruption - perception and victimization - and participation in protests, even in times of economic growth. Two possible mechanisms are discussed. Results suggest that the link between corruption and protests is not conditional to the economic cycle.
\end{abstract}

\section{Keywords}

Corruption; Protests; Participation; Accountability.

\section{Resumo}

Nos últimos anos, manifestaçóes de rua ocorreram no Brasil e em outros países latino-americanos para protestar contra os grandes escândalos de corrupçáo. Vários pesquisadores que estudam o caso do Brasil argumentaram que a recessão econômica foi uma das condiçóes que desencadearam a reação do público contra os escândalos de corrupção (MELO, 2016; HAGOPIAN, 2016), considerando que a opinião pública pode tolerar a corrupção em tempos de boom econômico - quando os programas sociais do governo podem ser expandidos - mas são menos propensos a aceitá-la em tempos de recessão econômica (BALAN, 2014). Este artigo utiliza dados da pesquisa LAPOP 2010 para mostrar que existe uma relação sistemática entre corrupção - percepção e vitimização - e participação em protestos, mesmo em tempos de crescimento econômico, no qual são discutidos dois possíveis mecanismos. Os resultados sugerem que o vínculo entre corrupção e participação em protestos não está condicionado pelo ciclo econômico.

\section{Palavras-chave}

Corrupção; Participação; Protestos; Accountability. 


\section{Introduction ${ }^{1}$}

During the last few years massive demonstrations broke out in Brazil, as well as in other Latin American countries, protesting against government corruption. Various scholars have argued that during times of economic recession, public opinion tends to be less tolerant with government corruption, which would explain recent massive demonstrations (MELO, 2016; HAGOPIAN, 2016). In contrast, during times of economic boom governments would have additional tools - such as government social programs - to mitigate the effect of corruption scandals on public opinion (BALAN, 2014).

This paper uses data from 2010 - a time when the region's average economic growth was $6,0 \%$ annually ${ }^{2}$ - to assess whether there is a link between corruption and citizen likelihood to participate in demonstrations. I show that when levels of corruption are high, citizens tend to participate more in protests. I use three alternative measures to assess this argument. First, I run a cross-national analysis with all Latin American countries to assess whether there is a systematic association between corruption perceptions and participation in protests at the country level. Second, I run a logistic model to assess whether at the individual level corruption victimization increases the odds to participate in protests. Third, I assess whether at the individual level, perception that the government is not doing enough to fight corruption increases the odds of participating in protests. In all cases I find a systematic association between corruption perception, victimization, and odds of participating in protests.

I discuss two alternative mechanisms to explain this finding. First, citizens could engage in protests where the main focus is government corruption (direct link). Second, citizens could perceive that when government corruption is high, participation in protests is necessary to achieve any policy goal (indirect link). That is,

\footnotetext{
${ }^{1}$ I gratefully acknowledge the Pardee Center for the Study of the Longer Range Future at Boston University for financial support, and participants at the Latin American Politics workshop at Boston University for helpful comments. A previous version of this work was presented at the Midwest Political Science Association Annual Meeting 2012; I am grateful to participants for helpful comments. I also thank the Latin American Public Opinion Project (LAPOP) and its major supporters (the United States Agency for International Development, the United Nations Development Program, the Inter-American Development Bank, and Vanderbilt University) for making the data available. I am also grateful to three anonymous reviewers for very helpful comments and suggestions. All errors are my responsibility.
}

${ }^{2}$ See IMF (2013). 
citizens could be more likely to channel their demands (of any kind) through protests when they have less trust in the government, given the high perceived levels of corruption.

The findings suggest that civil society has a strong role in controlling government corruption through protests, even during times of economic boom. Both victimization and perceptions of corruption increase societal participation in protests. In the next section, I discuss the concept of accountability and the role of vertical and horizontal accountability in government, and discuss political participation in the broader political context of Latin America in the last two decades. In the third section, I discuss prior research on the determinants of citizen participation in protests. In the fourth section, I use quantitative analysis to test the relationship between corruption and citizen participation in protests. In the fifth section, I discuss two possible mechanisms explaining the link between corruption and participation in protests. In the concluding section I discuss the findings and their implications.

\section{The mechanisms of accountability and the role of citizen participation in protests}

The concept of accountability refers to institutionalized mechanisms of oversight to control public officials and prevent them from committing wrongdoings. According to Scott Mainwaring accountability is "a formalized relationship of oversight and/or sanctions of public officials by other actors" (MAINWARING, 2003 , p. 7). Accountability demands the existence of actors capable of exercising oversight on public officials, the obligation of these officials to respond to the demands, and the possibility of imposing sanctions when they are responsible of unlawful acts. The actors demanding accountability might be government officials themselves - such as congressmen, judges, officials in oversight agencies -, or actors within the civil society such as citizens - through their vote -, journalists, and non government organizations.

Scholars have distinguished between two mechanisms of accountability: horizontal and vertical accountability. The first one refers to oversight of the executive power by the legislature and Judiciary and by other independent states agencies ${ }^{3}$. These state agencies should be "legally empowered - and factually willing and able - to take actions ranging from routine oversight to criminal sanctions or

\footnotetext{
${ }^{3}$ Examples of independent state agencies in charge of controlling the executive are accounting state offices, ombudsman, contralorías, and fiscalías (O’DONNELL, 1998).
} 
impeachment in relation to possibly unlawful actions or omissions by other agents or agencies of the state" (O'DONNELL, 1998, p. 5). The second mechanism, vertical accountability, refers to the oversight that voters exercise over the executive through regular elections, and citizens' expression of social demands through popular mobilizations. In sum, while horizontal accountability refers to intra-state mechanisms of oversight of public officials, vertical accountability refers to statesociety mechanisms of oversight of these officials (O'DONNELL, 1998).

In the literature on accountability several authors consider that regular and open elections, the most important mechanisms of vertical accountability, cannot guarantee effective controls on the executive (MANIN, PRZEWORSKI and STOKES, 1999; O’DONNELL, 1998). As Manin, Przeworski and Stokes (1999) argue, voters have only one instrument (the vote) to reward or punish multiple actions by the government; thus, when government wrongdoings are coupled with other more important and effective policies voters cannot point out with their vote that they support the latter but not the former. Similarly, O’Donnell (1998) argues that elections cannot secure strong mechanisms of accountability when there are high levels of party and voter volatility, political parties are weak, and elected candidates do not follow the platforms supported during their campaigns. In fact, corrupt politicians might be tempted to use illegal campaign funding in order to enhance their electoral chances (SPECK, 2012).

Smulovitz and Peruzzotti (2000 and 2003) and Peruzzotti (2009) argue that civil society can exert pressure on governments through other non electoral mechanisms, such as participating in protests, attending meetings, participating in interests groups, social movements, etc. These are the societal mechanisms of accountability. Societal accountability refers to the work of non-government organizations, journalists, and social mobilizations in demanding accountability to abusive governments. Citizen participation outside the electoral mechanisms is crucial to overcome the problem of "one instrument/multiple targets" as citizens can multiply the channels of communication with their government. Hence, according to these authors, protests should be considered an alternative mechanism to strengthen representation.

During the last decade, new collective actors expanded across the world, criticizing neo-liberal policies while promoting a new, more participatory conception of democracy (DELLA PORTA, 2013; DELLA PORTA and MATTONI, 2015; DELLA PORTA, 2015). These new actors included the Occupy Wall Street movement, the Spanish Indignados, and anti-globalization groups. In Latin America, 
these participatory practices were often promoted by left leaning governments. This was the case of the well known cases of participatory budget in Porto Alegre and Belo Horizonte (AVRITZER, 2002; GOLDFRANK, 2001), state promoted local community councils in Venezuela (MCCARTHY, 2012), the possibility to call recall elections to remove public officials in Venezuela and Bolivia, and other forms of state promoted participation (CAMERON, HERSHBERG and SHARPE, 2012).

However, the expansion of the role of civil society in Latin America was not only a result of participatory practices inspired by left-leaning governments. For instance, in the case of Brazil, Avritzer (2012) argues that in the post-dictatorship period there is a civil society with relatively higher levels of autonomy with respect to the state. That is, civil society associations (including voluntary religious associations and left leaning social movements among others) now have a relation of interdependence with the state, in stark contrast with the populist period, when civil society organizations where more dependent of state initiatives (AVRITZER, 2012). This increased autonomy has allowed a more critical role of those associations with respect to the state, which facilitates societal accountability.

\section{Understanding citizen participation in protests}

The literature on the determinants of citizen participation in general, and participation in protests in particular, has mostly focused on socio-economic variables that contribute to higher or lower levels of participation. At the same time, most of the studies have focused on the developed world, specially in the United States. Brady, Verba and Schlozman (1995) argue that resources as time, money and civic skills are good predictors of political participation, considering a wide range of activities: voting, contacting public officials, giving campaign money, participating in informal associations to solve community problems, being board member or attending community meetings, participating in protests. Accordingly, higher levels of education and income are associated with higher levels of participation (BRADY, VERBA and SCHLOZMAN, 1995).

Other studies focusing on political participation in the developing world have found less conclusive results on the relationship between income and participation. Bratton (2008) in a sample of fifteen African countries finds that poorer citizens were more likely to vote, more likely to attend a community meeting but less likely to attend a protest demonstration. Using an original survey for four Latin American countries (Peru, Venezuela, Chile and Argentina) Dunning (2009) finds that the 
middle classes participate in protests at higher rates than the lower classes. Thornton (2000) using data from 514 surveys conducted in Mexico in 1997 finds that informal-sector workers have higher rates of participation in protests than formalsector workers.

Looking at factors at the political system level Machado, Scartascini and Tommasi (2011) find that in countries with weaker institutions citizens contact less frequently their representatives in Congress and participate more in protests. Grimes (2013) finds that in societies with stronger civil society organizations and where there is political competition, press freedom and government transparency, corruption tends to be lower.

Scholars have also inquired on the effect of corruption perception on participation in elections. Kostadinova (2009) in a study on post-communist countries finds that perceptions of corruption have a slight mobilizing effect among voters. Caillier (2010) finds that in the state of Luisiana citizens were likely to vote when they perceived more corruption. Chong et al. (2011) show that information about corruption decreases voter turnout and both incumbent's and challenger's share of votes in local elections in Mexico.

Arguably, corruption affects citizens' satisfaction with their government and encourages them to participate in this kind of activity. In a comparative study of four Latin American countries Seligson (2002) shows that corruption negatively affects beliefs in the regime legitimacy and trust in the political institutions of the country. Pérez-Liñán (2007) argues that corruption scandals and citizen protests were the main factors causing presidential impeachment in Latin America.

While most previous research considers the determinants of various forms of participation (with participation in protests being only one case of participation), some authors consider that not all forms of participation should be included in one single category. In particular, Tilly and Tarrow (2006) conceptualize participation in protests as a type of political action (contentious politics) which differs from other more institutionalized, scheduled forms of participation (such as voting or participating in associational meetings). They consider contentious politics as a collective making of a claim that is episodic and attempts to coordinate efforts on behalf of a shared interest or program targeting the government (as a mediator, claimant or as an object of claims) (TILLY and TARROW, 2006). Political demonstrations are a specific type of performance to express claims, involving an orderly passage of a collective actor through the public space on behalf of some claim, identity or program (TILLY and TARROW, 2006). These authors consider that a 
key aspect of contentious politics is the fact that it is episodic, as opposed to scheduled public acts. In that sense, street demonstrations differ from other forms of scheduled political participation, such as voting or participating in associational meetings (TILLY and TARROW, 2007).

Machado et al. (2011) conceptualize participation in protests as a "political technology" which differs from other forms of participation, such as contacting members of congress, in their degree of institutionalization. While "institutionalized political participation" includes voting in elections, writing to representatives, and other forms of participation through the institutional arena, participation in protests is an "alternative political technology" (along with other forms of non institutionalized participation) which tends to take place in countries where institutions are weak.

This study follows this framework in that it attempts to understand the causes of participation as a specific form of political participation. It argues that in contexts of low government transparency, this type of political participation tends to increase.

Two recently published papers have addressed the link between corruption and political participation. Both articles, using Americas Barometer data, find a link between corruption perceptions and victimization and various forms of political participation in Brazil (BONIFÁCIO and RIBEIRO, 2016) and in the Americas (BONIFÁCIO and PAULINO, 2015). They use factorial analysis to create various aggregate indicators of political participation, including an indicator that combines participation in protests and signing petitions, which they label protest activism.

This study departs from their analysis in three ways. First, it includes crossnational evidence (along with the individual level evidence) which shows that at the country level, higher aggregate perceptions of corruption is associated with higher aggregate levels of participation in protests. Second, following Machado et al. (2011) I understand participation in protests as a distinctive form of participation, which differs from other institutionalized forms of expressing political demands (such as signing petitions). That is, I test whether in the absence of government transparency; non-institutionalized forms of participation tend to increase. While Machado et al. (2011) find a link between participation in protests and low levels of institutionalization I show that corruption has an independent effect on participation in protests. Third, I include an additional explanatory variable: whether subjects believe that the government is not trying to do enough to fight corruption. That is, I 
show that that subjects tend to participate more in protests when they perceive weak mechanisms of horizontal accountability.

\section{Data, methods and results}

To test the relationship between corruption and participation in protests I use data from Transparency International (2010) and from the Americas Barometer survey The Corruption Perceptions Index is an indicator of corruption compiled annually by Transparency International; it measures perceptions of the degree of corruption as seen by business people, risk analysts, and the general public, and ranges between 10 (highly clean) and 0 (highly corrupt). The Americas Barometer survey measures citizens' perceptions and behavior on a number of issues, ranging from system support, political tolerance, citizen participation, local government, corruption, and authoritarianism. Surveys are implemented on a national probability design, and participants are voting age adults; it covers 26 countries in the Americas 4 .

In Table 1 we can see the results of an OLS regression using perceived corruption as the independent variable and participation in protests as the dependent variable. It includes all countries in Latin America (i.e. excluding North America and the Caribbean). The perceived corruption variable is based on the Corruption Perceptions Index from Transparency International and ranges from 0 (highly corrupt) to 10 (highly clean). The participation in protests variable was based on the Americas Barometer survey. This table also includes observations of the 2008 survey. Individuals were asked "In the last twelve months, have you participated in a demonstration or protest march?" The variable "political participation" captures the percentage of citizens who affirmed having participated in a demonstration in the last year.

In that table we can see that countries with higher levels of perceived corruption tend to have higher rates of participation in protests. In model $1 \mathrm{I}$ control for education. Model 2 includes GDP per capita as a control. In both cases the result is significant at the 0.01 level.

\footnotetext{
${ }^{4}$ Countries included in the survey are Argentina, Belize, Bolivia, Brazil, Canada, Colombia, Costa Rica, Chile, Dominican Republic, Ecuador, El Salvador, Guatemala, Guyana, Haiti, Honduras, Jamaica, Mexico, Nicaragua, Panama, Paraguay, Peru, Trinidad and Tobago, Suriname, United States, Uruguay, and Venezuela.
} 
Table 1 - OLS Estimates on the Effect of Corruption on Participation in Protests in Latin America:

\begin{tabular}{l|c|c}
\multicolumn{1}{c|}{ Variable } & $\begin{array}{c}\text { Participation in Protests } \\
(1)\end{array}$ & $\begin{array}{c}\text { Participation in Protests } \\
(2)\end{array}$ \\
\hline Corruption Perceptions & $\begin{array}{c}-2.67^{* * *} \\
(0.77)\end{array}$ & $\begin{array}{c}-2.51^{* * *} \\
(0.75)\end{array}$ \\
\hline Avg Years of Education (Women) & -1.60 & -0.57 \\
& $(1.44)$ & $(1.49)$ \\
\hline Avg Years of Education (Men) & $4.21^{* *}$ & $4.26^{* *}$ \\
& $(1.60)$ & $(1.54)$ \\
\hline GDP per capita & & $-0.01^{*}$ \\
\hline R-squared & & $(0.00)$ \\
\hline
\end{tabular}

Standard errors in parenthesis

${ }^{* * *} \mathrm{p} \leq 0.01,{ }^{* *} \mathrm{p} \leq 0.05,{ }^{* * *} \mathrm{p} \leq 0.1$

Source: Own elaboration based on Transparency International and LAPOP survey.

Note: OLS regression model.

We can see that at the aggregate level countries with higher levels of perceived corruption have higher rates of citizen participation in protests. In the two models the percentage of citizens who participated in a demonstration in the last year drop as we go down on the Corruption Perceptions Index scale, results are significant at the 0.01 level.

But what happens at the individual level? Do individuals who have suffered corruption in their personal experiences tend to participate more in protests? To answer this question I run a new model. Individuals in the Americas Barometer survey were asked the following question: "In the last twelve months, did any government employee asked you for a bribe?" The advantage of this second measure of corruption is that it gets at real experiences with corruption, whereas the Corruption Perception Index measures perceptions of corruption.

In Table 2 I run a logistic model using a dummy variable to capture individuals who participated in protests in the last year as the dependent variable, and a dummy variable capturing if any public official has asked the surveyed for a bribe in the last year. Tables 2 and 3 include respondents from all the American countries (including North American countries and the Caribbean). We can see that individuals who have been asked for a bribe have higher odds of participating in 
protests. In model $1 \mathrm{I}$ use education as control and in model $2 \mathrm{I}$ include income as control. The results are consistent after including these controls. In model 3 I control for trust in institutions; individuals in the survey were asked "to what extent do you trust in the political institutions of your country?" Responses range from 1 (not at all) to 7 (a lot). By introducing trust in institutions I intend to control for the argument that in countries with weaker institutions people participate more in protests (MACHADO et al., 2011); if the argument is correct then people who trust in a lesser degree in the institutions of their countries would have higher possibilities of participating in demonstrations. As we can see, even controlling for trust in institutions the result is significant. In fact, according to this model, people who trust more in their institutions have higher chances of participating in protests, contrary to what should be expected according to these authors. In model 4 I control for the political ideology of the respondent; individuals in the survey were asked to define themselves in terms of political ideology in a scale ranging from 1 (left) to 10 (right).

In all models we can see that individuals who have been asked for a bribe have higher odds of participating in protests, the results are significant at the 0.01 level. We should note that individuals who experience corruption are likely to do so with lower level public officials, such as policemen, lower level administrative bureaucrats, etc. Even if they appointed government officials might not be responsible for such corruption, there are various ways in which such experience could motivate dissatisfaction and higher odds of participating in protests. First, they could blame national government for not doing enough to fight corruption within lower level bureaucrats. Second, their motivation to participate in protests might be directed to protests against all public officials, demanding more government transparency at all levels of administration. Third, when they experience corruption, they could be motivated to participate in protests demanding any policy goal, not necessarily related to corruption, as citizens who experience dissatisfaction with democracy might be more inclined to participate in protests. This indirect link is another possible explanation of why everyday experiences with corruption might motivate participation in protests of any kind. Further discussion on this indirect link is presented in the next section. 
Table 2 - Odds Ratio of Participating in Demonstrations after Having Been Asked for a Bribe by a Public Official in the Americas: 2010

\begin{tabular}{|c|c|c|c|c|}
\hline Variable & $\begin{array}{c}\text { Participation } \\
\text { in Protests } \\
\text { (1) }\end{array}$ & $\begin{array}{c}\text { Participation } \\
\text { in Protests } \\
\text { (2) }\end{array}$ & $\begin{array}{c}\text { Participation } \\
\text { in Protests } \\
\text { (3) }\end{array}$ & $\begin{array}{c}\text { Participation } \\
\text { in Protests } \\
\text { (4) }\end{array}$ \\
\hline Corruption Victimization & $\begin{array}{c}2.42^{* * *} \\
(0.04)\end{array}$ & $\begin{array}{c}2.38^{* * *} \\
(0.04)\end{array}$ & $\begin{array}{c}2.39^{* * *} \\
(0.04)\end{array}$ & $\begin{array}{c}2.29^{* * *} \\
(0.05)\end{array}$ \\
\hline Education & $\begin{array}{c}1.29^{* * *} \\
(0.18)\end{array}$ & $\begin{array}{c}1.27^{* * *} \\
(0.02)\end{array}$ & $\begin{array}{c}1.27^{* * *} \\
(0.02)\end{array}$ & $\begin{array}{c}1.28^{* * *} \\
(0.03)\end{array}$ \\
\hline Income & & $\begin{array}{c}1.03^{* * *} \\
(0.01)\end{array}$ & $\begin{array}{c}1.03^{* * *} \\
(0.01)\end{array}$ & $\begin{array}{c}1.04^{* * *} \\
(0.01)\end{array}$ \\
\hline Trust in Institutions & & & $\begin{array}{c}1.04^{* * *} \\
(0.02)\end{array}$ & $\begin{array}{c}1.06^{* * *} \\
(0.02)\end{array}$ \\
\hline Political Ideology & & & & $\begin{array}{c}0.92^{* * *} \\
(0.01)\end{array}$ \\
\hline Pseudo R-Squared & 0.02 & 0.02 & 0.02 & 0.03 \\
\hline
\end{tabular}

Standard errors in parenthesis

${ }^{* * *} \mathrm{p} \leq 0.01,{ }^{* *} \mathrm{p} \leq 0.05,{ }^{* * *} \mathrm{p} \leq 0.1$

Source: Own elaboration based on LAPOP survey.

Note: Logistic model.

Is the perception that the government is not doing enough to fight corruption another factor that drives citizen participation in protests? When citizen believe that they are under a corrupt system and the government is not doing enough to fight corruption they might be more prone to mobilize in demonstrations to show their dissatisfaction. Table 3 inquires whether individuals who perceive that the government is not trying to combat government corruption are more likely to participate in demonstrations. Individuals surveyed in the Americas Barometer were asked "To what extent would you say that the current government combats government corruption?" and had to choose a numeric response ranging from 1 ("not at all") to 7 ("a lot"). Response 1 ("not at all") is the baseline.

In model $1 \mathrm{I}$ use education and income as controls. We can see that as we move from the "not at all" response to higher levels of trust in governmental response to corruption the odds of participating in demonstrations decreases. For example, as we move from 1 to 2 in the response the odds of participating will decrease by a factor of 0.87 ; moving from 1 to 3 in the response scale will decrease the odds of 
participating by a factor of 0.76 . All the statistically significant results (responses 3, 4 and 5) show a decrease in the odds when compared with response number 1.

In model 2 I additionally control for party identification. We can see a similar effect, with responses 3, 4, 5 and 6 showing a statistically significant decrease in the odds of participating in demonstrations. In model 3, I include trust in institutions as control. Here, only responses 3 and 5 show statistically significant results (at the 0.05 level).

Table 3 - Odds Ratio of Participating in Demonstrations Depending Based on Perception on Whether the Government is Trying to Combat Government Corruption in the Americas: 2010

\begin{tabular}{|c|c|c|c|}
\hline Variable & $\begin{array}{c}\text { Participation } \\
\text { in Protests } \\
(1)\end{array}$ & $\begin{array}{c}\text { Participation } \\
\text { in Protests } \\
(2)\end{array}$ & $\begin{array}{c}\text { Participation } \\
\text { in Protests } \\
(3)\end{array}$ \\
\hline $\begin{array}{l}\text { Government Fights Corruption ( } 2 \text { on } 1-7 \\
\text { scale). }\end{array}$ & $\begin{array}{l}0.87^{*} \\
(0.08)\end{array}$ & $\begin{array}{c}0.83 \\
(0.14)\end{array}$ & $\begin{array}{c}0.84 \\
(0.14)\end{array}$ \\
\hline $\begin{array}{l}\text { Government Fights Corruption ( } 3 \text { on } 1-7 \\
\text { scale). }\end{array}$ & $\begin{array}{l}0.76^{* * *} \\
(0.09)\end{array}$ & $\begin{array}{l}0.75^{* * *} \\
(0.14)\end{array}$ & $\begin{array}{l}0.78^{* *} \\
(0.14)\end{array}$ \\
\hline $\begin{array}{l}\text { Government Fights Corruption ( } 4 \text { on } 1-7 \\
\text { scale). }\end{array}$ & $\begin{array}{c}0.73^{* * *} \\
(0.09)\end{array}$ & $\begin{array}{l}0.79^{* *} \\
(0.13)\end{array}$ & $\begin{array}{l}0.83^{*} \\
(0.13)\end{array}$ \\
\hline $\begin{array}{l}\text { Government Fights Corruption ( } 5 \text { on } 1-7 \\
\text { scale). }\end{array}$ & $\begin{array}{c}0.74^{* * *} \\
(0.09)\end{array}$ & $\begin{array}{c}0.76^{* * *} \\
(0.13)\end{array}$ & $\begin{array}{l}0.80^{* *} \\
(0.13)\end{array}$ \\
\hline $\begin{array}{l}\text { Government Fights Corruption ( } 6 \text { on } 1-7 \\
\text { scale). }\end{array}$ & $\begin{array}{l}0.89^{*} \\
(0.08)\end{array}$ & $\begin{array}{l}0.80^{* *} \\
(0.14)\end{array}$ & $\begin{array}{c}0.85 \\
(0.13)\end{array}$ \\
\hline $\begin{array}{l}\text { Government Fights Corruption ( } 7 \text { on } 1-7 \\
\text { scale). }\end{array}$ & $\begin{array}{c}1.10 \\
(0.07)\end{array}$ & $\begin{array}{c}1.10 \\
(0.99)\end{array}$ & $\begin{array}{l}1.23^{*} \\
(0.09)\end{array}$ \\
\hline Education & $\begin{array}{c}1.08^{* * *} \\
(0.01)\end{array}$ & $\begin{array}{c}1.08^{* * *} \\
(0.01)\end{array}$ & $\begin{array}{c}1.01^{* * *} \\
(0.01)\end{array}$ \\
\hline Income & $\begin{array}{c}1.00 \\
(0.01)\end{array}$ & $\begin{array}{c}0.99 \\
(0.01)\end{array}$ & $\begin{array}{c}1.01 \\
(0.01)\end{array}$ \\
\hline Party Identification & & $\begin{array}{c}1.00 \\
(0.01)\end{array}$ & $\begin{array}{c}1.00 \\
(0.01)\end{array}$ \\
\hline
\end{tabular}




\begin{tabular}{l|c|c|c}
\hline Trust in Institutions & & & $\begin{array}{c}0.94^{* * *} \\
(0.02)\end{array}$ \\
\hline Pseudo R-Squared & 0.01 & 0.02 & 0.02 \\
\hline
\end{tabular}

Standard errors in parenthesis

*** $\mathrm{p} \leq 0.01,{ }^{* *} \mathrm{p} \leq 0.05,{ }^{* * *} \mathrm{p} \leq 0.1$

Source: Own elaboration based on LAPOP survey.

Note: Logistic model.

Government Fights Corruption: 1-7 point scale (1: Not at all, 7: A lot). Answer 1 is the baseline.

As we could see, at the national level countries with higher levels of perceived corruption have higher rates of citizen participation in protests, at the individual level citizens who had a direct experience with corruption are more likely to participate in protests and citizens who think that the government is not doing its job in fighting corruption are more likely to participate in protests. These results bear important consequences on the way we should think about accountability. Civil society can play an important role in the absence of an effective monitoring of government transparency. In the next section, I discuss two possible mechanisms linking corruption victimization and perception with participation in protests.

\section{The possible links between corruption and participation in protests: direct and indirect mechanism}

While results presented in the three tables show a systematic link between corruption and protests, this link doesn't necessarily entail that all protests are demanding government transparency. Higher levels of corruption could increase street protests by different mechanisms. In this section, I discuss two possible mechanisms explaining the relation between corruption and participation in protests.

The first one is a direct mechanism leading from corruption (victimization or perception) to participation in protests. That is, citizens who experience or perceive high levels of corruption might decide to go out to the street and protest against government corruption. Massive demonstrations against government corruption have not been uncommon in Latin America, particularly in recent years. For instance, in Brazil in 2015 massive protests were carried out as a response to the Lava Jato corruption scandal, following various waves of demonstrations (starting in 2013) protesting against the organization of the World Cup, police violence and the rise of the price in public transport. The same year, in Honduras, massive street protests broke out as a response to a corruption scandal affecting the national security 
institute; while in Guatemala, a corruption scandal affecting the country's vicepresident also triggered massive protests.

Similar massive protests against government corruption were carried out during the decade of the nineties. In fact, Pérez-Liñán (2007) argues that one of the factors leading to the impeachment of governments accused of corruption is the existence of massive street demonstrations. The cases where massive street demonstrations were triggered by corruption scandals include Venezuela in 19921993, Brazil in 1992, Ecuador in 1997, Nicaragua in 2002, Paraguay in 1998-1999, Peru in 2000 (HOCHSTETLER, 2006). In all these cases, the street demonstrations were coupled with legislative activity and ended up in government impeachment. The absence of popular mobilization also appeared to be a core factor in the cases in which Congress failed to remove presidents strongly suspected of having engaged in illegal behavior. These were the cases of Ecuador in 1987, Peru in 1991-1992, Paraguay in 1994, and Colombia in 1995-1996 (HOCHSTETLER, 2006).

An alternative indirect mechanism could also explain the link between corruption and participation in protests. According to this mechanism, citizens who perceive or suffered corruption consider that government institutions do not function properly, and hence are more willing to take action through street protests rather than through institutionalized mechanisms. These protests could channel demands unrelated to corruption, such as social demands, crime related demands, etc.

This argument is consistent with Seligson (2002) who shows that corruption undermines trust in institutions, and consistent with Machado et al. (2011) argument that in countries with weak institutions, citizens tend to channel their demands through street demonstrations. That is, if citizens have lower trust in their institutions given the high levels of corruption, they would be more likely to channel their demands through participations in protests. In contexts with lower levels of corruption, citizens might be inclined to channel their demands through other institutionalized mechanisms. However, as stated above, in most models in Tables 2 and 3 the effect of corruption (victimization and feelings that the government is not doing enough to fight it) on the odds of participating in protests is significant, even after controlling for trust in institutions.

\section{Conclusions}

This paper has argued that there is a systematic link between corruption and civil society mobilization, even in times of economic growth. The findings suggest that societal mechanisms of accountability are not conditioned by the economic cycle. We 
saw that at the national level countries higher levels of perceived corruption are associated with higher rates of participation in protests, and that at the individual level citizens who have been asked to pay a bribe and citizens who think that the government is not doing enough to fight corruption tend to participate more in protests. While it could be true that during times of economic recession, public reaction towards corruption scandals could increase, these findings show that even in the absence of such crisis, there is a systematic link between corruption and participation in protests.

The argument underlines the importance of alternative mechanisms of vertical accountability in the form of participation in protests. In particular, during times of economic boom citizens are more likely to support corrupt governments if they can use additional resources to improve social programs and carry out public works (BALAN, 2014; PEREIRA and MELO, 2015). The findings presented in this paper suggest that even during those times, citizens will increase pressure on governments with street demonstrations.

Results are consistent using both measures of corruption perception -which could be subjective- and victimization. That is, the link holds both when citizens perceive that there are high levels of corruption in government and when they suffer corruption in their personal experience. We should note that corruption victimization doesn't necessarily imply contacts with high level government officials. Most likely, common citizens suffered corruption in their interactions with lower level public officials. However, such experiences might still promote citizen participation in protests.

Two possible mechanisms explaining the link between corruption and participation in protests were discussed. A first, direct mechanism, posits that citizens go out to the street to protests against government corruption demanding more transparency. A second, indirect mechanism, posits that when citizens perceive and experience corruption at higher levels, they are more likely to go out to the streets to promote any demand, even if unrelated to corruption. This second explanation implies that for observers it might not be immediately obvious the relationship between protests and corruption, as those protests could have any policy goal unrelated with corruption. The fact that citizens promote any policy demand through participation in protests, and not through any other institutionalized mechanism, might be a result of a context of high levels of corruption. However, results hold even after controlling for trust in institutions, which suggest a direct 
effect of corruption (perception and victimization) on the possibilities of participating in protests.

- Alejandro Avenburg é Doutor em Ciência Politica, pela Universidade de Boston. É Professor na Escola de Política e Governo da Universidade Nacional de San Martín. E-mail: avenburg@bu.edu.

\section{Referências}

AMERICAS BAROMETER. The Americas Barometer by the Latin American Public Opinion Project (LAPOP). Disponível em: <www.LapopSurveys.org>. Acesso em 11 jul. 2011.

AVRITZER, Leonardo. Sociedade civil e Estado no Brasil: da autonomia à interdependência política. Opinião Pública, v. 18, n. 2, p. 383-398, 2012.

AVRITZER, Leonardo. Modelos de Deliberação Democrática: uma análise do orçamento participativo no Brasil. In: DE SOUSA SANTOS, Boaventura (Org.). Democratizar a Democracia: Os Caminhos de Democracia Participativa. Rio de Janeiro: Civilização Brasileira, 2002. p. 561-591.

AVRITZER, Leonardo; DE SOUSA SANTOS, Boaventura. Introdução: para ampliar o cânone democrático. In: DE SOUSA SANTOS, Boaventura (Org.). Democratizar a Democracia: Os Caminhos de Democracia Participativa. Rio de Janeiro: Civilização Brasileira, 2002. p. 39-82.

BALAN, Manuel. Surviving Corruption in Brazil: Lula's and Dilma's Success Despite Corruption Allegations, and Its Consequences. Journal of Politics in Latin America, v. 6, n. 3, p. 67-93, 2014.

BONIFÁCIO, Robert; PAULINO, Rafael. Corruption and Political Participation in the Americas and the Caribbean. Brazilian Political Science Review, v. 9, n. 2, p. 54-80, 2015.

BONIFÁCIO, Robert; RIBEIRO, Ednaldo. Corrupção e Participação Política no Brasil: diagnósticos e consequências. Revista Brasileira de Ciência Política, n. 20, p. 7-42, 2016.

BRADY, Henry E.; VERBA, Sidney; SCHLOZMAN, Lehman. Beyond SES: A Resource Model of Political Participation. American Political Science Review, v. 89, n. 2, p. 271-294, 1995.

BRATTON, Michael. Poor People and Democratic Citizenship in Africa. In: KRISHNA, Anirudh (Ed.). Poverty, Participation, and Democracy: A Global Perspective. Cambridge: Cambridge University Press, 2008. p. 28-64.

CAILLIER, James. Citizen Trust, Political Corruption, and Voting Behavior: Connecting the Dots. Politics and Policy, n. 38, v. 5, p. 1015-1035, 2010.

CAMERON, Maxwell; HERSHBERG, Eric; SHARPE, Kenneth E. (Eds). New Institutions for Participatory Democracy in Latin America: Voice and Consequence. New York, Pelgrave, 2012.

CHONG, Alberto; DE LA O, Ana L.; KARLAN, Dean; WANTCHEKON, Leonard. Looking Beyond the Incumbent: the Effects of Exposing Corruption on Electoral Outcomes. NBER Working Paper, 2011. 
DELLA PORTA, Donatella. Can Democracy be Saved? Participation, Deliberation and Social Movements. Malden: Polity Press, 2013.

DELLA PORTA, Donatella. Social Movements in Times of Austerity: Bringing Capitalism Back into Protest Analysis. Cambridge: Polity Press, 2015.

DELLA PORTA, Donatella; MATTONI, Alice (Eds.). Spreading Protest: Social Movements in Times of Crisis. Colchester, UK: ECPR Press, 2015.

DUNNING, Thad. Direct Action and Associational Participation: Problem-Solving Repertoires of Individuals. In: COLLIER, Ruth Berins and HANDLIN, Samuel (Org.). Reorganizing Popular Politics: Participation and the New Interest Regime in Latin America. Pennsylvania: The Pennsylvania State University Press, 2009. p. 95-131.

GRIMES, Marcia. The Contingencies of Societal Accountability: Examining the Link Between Civil Society and Good Government. Studies in International Comparative Development, v. 48, n. 4, p. 380-402, 2013.

GOLDFRANK, Benjamin. Deepening Democracy through Participation? A Comparative Analysis of Three Cities. Paper presented at the 2001 meeting of the Latin American Studies Association. Washington, 2001.

HAGOPIAN, Frances. Brazil's Accountability Paradox. Journal of Democracy, v. 27, n. 3, p. 119$128,2016$.

HOCHSTETLER, Kathryn. Rethinking Presidentialism: Challenges and Presidential Falls in South America. Comparative Politics, v. 38, n. 4, p. 401-418, 2006.

IMF. World Economic Outlook. 2013. Disponível em: <http://www.imf.org/external/pubs/ft/weo/2013/01/pdf/text>. Acesso em 06 jul. 2017.

KOSTADINOVA, Tatiana. Abstain or Rebel: Corruption Perceptions and Voting in East European Elections. Politics \& Policy, v. 37, n. 4, p. 691-714, 2009.

MACHADO, Fabiana; SCARTASCINI, Carlos; TOMMASI, Mariano. Political Institutions and Street Protests in Latin America. Journal of Conflict Resolution, v. 55, n. 3, p. 340-365, 2011.

MAINWARING, Scott. Introduction: Democratic Accountability in Latin America. In: Scott MAINWARING and WELNA, Christopher (Org.). Democratic Accountability in Latin America. New York: Oxford University Press, 2003. p. 3-33.

MANIN, Bernard; PRZEWORSKI, Adam; STOKES, Susan (Org.). Democracy, Accountability and Representation. Cambridge: Cambridge University Press, 1999.

MCCARTY, Michael M. The Possibilities and Limits of Politicized Participation: Community Councils, Coproduction, and Poder Popular in Chávez's Venezuela. In: CAMERON, Maxwell; HERSHBERG, Eric and SHARPE, Kenneth E. (Org.). New Institutions for Participatory Democracy in Latin America: Voice and Consequence. New York: Pelgrave, 2012.

MELO, Marcus André. Crisis and Integrity in Brazil. Journal of Democracy, v. 27, n. 2, p. 50-65, 2016.

O’DONNELL, Guillermo. Horizontal Accountability in New Democracies. Journal of Democracy, v. 9, n. 3, p. 112-26, 1998.

PEREIRA, Carlos; MELO, Marcus André. Reelecting Corrupt Incumbents in Exchange for Public Goods: Rouba mas Faz in Brazil. Latin American Research Review, v. 50, n. 4, p. 88-115, 2015. 
28 | Alejandro Avenburg

PÉREZ-LIÑÁN, Aníbal. Presidential Impeachment and the New Political Instability in Latin America. Cambridge: Cambridge University Press, 2007.

PERUZZOTTI, Enrique. Representative Democracy as Mediated Politics: Rethinking the Links between Representation and Participation. London School of Economics, NGPA Working Paper, 2009.

SELIGSON, Mitchell A. The Impact of Corruption on Regime Legitimacy: A Comparative Study of Four Latin American Countries. The Journal of Politics, v. 64, n. 2, p. 408-433, 2002.

SMULOVITZ, Catalina; PERUZZOTTI, Enrique. Societal Accountability in Latin America. Journal of Democracy, v. 11, n. 4, p. 147-158, 2000 .

SMULOVITZ, Catalina; PERUZZOTTI, Enrique. Societal and Horizontal Controls: Two Cases of a Fruitful Relationship. In: MAINWARING, Scott; WELNA, Christopher (Org.). Democratic Accountability in Latin America. New York: Oxford University Press, 2003. p. 309-332.

SPECK, Bruno. O Financiamento Político e a Corrupção no Brasil. In: DE CÁSSIA BIASON, Rita (Org.). Temas de Corrupção Política no Brasil. São Paulo: Balão Editorial, 2012. p. 49-97.

THORNTON, Douglass. Political Attitudes and Participation of Informal and Formal Sector Workers in Mexico. Comparative Political Studies, v. 33, n. 10, p. 1279-1309, 2000.

TILLY, Charles; TARROW, Sidney. Contentious Politics. Lanham: Paragon Press, 2006.

TILLY, Charles; TARROW, Sidney. Contentious Politics and Social Movements. In: BOIX, Carles; STOKES, Susan (Org.). Oxford Handbook of Comparative Politics. New York: Oxford University Press, 2007. p. 435-460.

TRANSPARENCY INTERNATIONAL. Corruption Perceptions Index. 2010. Disponível em: <:http://www.transparency.org/>. Acesso em 11 nov. 2011.

Texto recebido em 02 de setembro de 2017. Aprovado em 16 de novembro de 2017. 